\title{
Development of Visual Basic Application Based Learning Media on Flat Building Materials
}

\author{
Indah Puspita Sari \\ Pendidikan Matematika, IKIP Siliwangi, indah@ikipsiliwangi.ac.id \\ Adi Nurjaman* \\ Pendidikan Matematika, IKIP Siliwangi, nurjamanadi@ikipsiliwangi.ac.id
}

\begin{abstract}
This study aims to produce learning media based on a visual basic application of triangles and rectangles. This research is research and development. The method used in this research is a research and development method with a 4-D model (Four-D Model). This development model is modified into 3-D, only until the development stage (Develop). The instrument used in this study was a questionnaire used to assess the validity and practicality of the teaching materials. The validity questionnaire was given to 2 experts in the field of mathematics education and media while the practicality questionnaire was given to students. This research produces learning media based on a visual basic application that is valid, very practical, and effective for use in learning
\end{abstract}

Keywords: Visual Basic Application, Learning Media, Flat Building

ABSTRAK

Penelitian ini bertujuan untuk menghasilkan media pembelajaran berbasis visual basic application pada materi segitiga dan segiempat. Penelitian ini merupakan penelitian dan pengembangan Metode yang digunakan dalam penelitian ini adalah metode penelitian dan pengembangan (Research and Development) dengan model 4-D (Four$D$ Model). Model pengembangan ini dimodifikasi menjadi 3-D, hanya sampai pada tahap pengembangan (Develop). Instrumen yang digunakan dalam penelitian ini berupa angket yang digunakan untuk menilai kevalidan dan kepraktisan dari bahan ajar. Angket kevalidan diberikan kepada 2 orang ahli pada bidang pendidikan matematika dan media sedangkan angket kepraktisan diberikan kepada siswa. Penelitian ini menghasilkan media pembelajaran berbasis visual basic aplication yang valid, sangat praktis, dan efektif digunakan dalam pembelajaran.

Kata Kunci: Visual Basic Aplication, Media Pembelajaran, Bangun Datar.

\section{INTRODUCTION}

The Covid 19 pandemic has had a tremendous impact in almost all fields, one of which is in the field of education. With the covid 19 viruses, the learning process that was initially carried out face-to-face has turned into distance learning or online learning so that the existence of technology is currently considered very important. Teachers can use technology as a learning medium in delivering material through several applications, such as the zoom application, Spada, google classroom, google Meetings, or other applications. In addition, teachers can also develop learning media by utilizing existing technology so that students can find their own concepts from the material being studied so that learning is more meaningful. So that student learning styles are one of the starting points to identify students' multiple abilities and intelligence (O'neil, 2012)

Learning media is a tool in the learning process and serves to clarify the message that you want to convey. Learning media by Kemp \& Dayton (Azhar, 2007), can fulfill three main functions if the media is used for a large number of individuals, groups, or groups of listeners, namely motivating interests and actions, presenting information, and giving instructions. The types of media based on 
the development of technology according to (Azhar, 2007) were print technology media, audiovisual technology result media, computer-based technology result media, print technology combined media with computers. Computer-based technology learning media deserves to be considered as an alternative to learning during the current covid 19 pandemics.

ICT-based or technology-based learning contributes significantly higher to student learning outcomes (Shih et al., 2010; Yen et al., 2010). The influence of technology is huge in the field of education because it can improve the quality of learning, strategies, models, and assessments in accordance with the competence of students and teachers (Bond \& Bedenlier, 2019; Briz-Ponce et al., 2017; Habes et al., 2018; Sung et al., 2016). In addition, using technology can increase students' creativity in exploring their abilities (Briz-Ponce et al., 2017; Fabian et al., 2016; Habes et al., 2018; Harris et al., 2016; Henriksen et al., 2019; Ndofirepi et al., 2018).

Azhar (2007) states that learning with a computer can hone a variety of exercises as there are various illustrations, animations, and graphics. Learning with this computer can attract students because learning becomes more fun and interesting than when the teacher explains the material in front of the class. In the development of computer-based media, teachers can take advantage of various applications such as Microsoft PowerPoint, Microsoft Excel, Microsoft Word, adobe animation, adobe flash, and so on

Microsoft Excel is part of Microsoft office that serves to process data in the form of text and numbers. This view of Microsoft Excel is a spreadsheet or worksheet making it easier for its users to operate it. According to Tjihardji (Nuryanto \& Zaki, 2012), Microsoft Excel software is a spreadsheet (paper), database, graph, and macro (automation command or program) program. Microsoft Excel is widely used by the public as a tool to accomplish several tasks that are performed repeatedly and continuously. The following are some examples of common uses of Microsoft Excel that are commonly found including 1) Managing value data, managing payroll data, and managing schedules and agendas of activities; 2) Manage transactions and generate invoices and print transaction receipts; and 3) Manage to chart progress from data stored in data dimensions in excel

One of the ICT-based media is Microsoft Excel, and the software is rich in mathematical functions for data processing. Microsoft Excel also provides images such as Shapes, Pictures, Graphics, and Diagrams (Bernard \& Senjayawati, 2019), but nowadays most people still associate data processing cells with graphs such as running Shapes, Picture, Graphs, and Diagrams into dynamic shapes by using The Visual Basic Application for Microsoft Excel.

VBA-based learning media can be designed in such a way as to solve a problem in calculating the area and circumference of a flat build easily and attractively. Students can discover for themselves the broad and roving formula of a flat build from their experience when solving the problem. Therefore VBA-based learning media can be software for learning mathematics. Based on this background, researchers are interested in developing a learning medium on flat build materials by utilizing VBA. The flat build material is a material that is difficult for students to understand so researchers want to produce a learning medium that can make it easier for students to understand the material and students can learn fun. 


\section{METHOD}

The methods used in this study are research and development methods (Research and Development) with the model 4-D (Four-D Model). According to, Semmel dan Semmel (Gorbi Irawan et al., 2018) this model called 4-D consists of 4 stages: Define, Design, Develop, and Disseminate. This development model was modified to $3-D$, only to the development stage

The instruments used in this study are questionnaires used to assess the validity and practicality of teaching materials. The validity questionnaire is given to 2 experts in the field of mathematics and media education based on their expertise, while the practicality questionnaire is given to teachers and students to assess practicality based on their experiences during the learning process

1. Validity Test

Learning media will be used first in the validity test by two experts in the field of mathematics education and media. The formula used to calculate the percentage of validation according to Arikunto (Taufik \& Kristanto, 2018) as follows :

$$
\text { validation percentage }=\frac{\text { number of scores earned }}{\text { total score }} \times 100 \%
$$

Tabel 1. Interpretation of Validity

\begin{tabular}{cc}
\hline Percentage of Achievements & Interpretation \\
\hline $\mathrm{P} \geq 75 \%$ & Very valid \\
$55 \% \leq \mathrm{P}<75 \%$ & Valid \\
$40 \% \leq \mathrm{P}<55 \%$ & enough \\
$\mathrm{P}<40 \%$ & invalid \\
\hline
\end{tabular}

2. Practicality Test

The formula for calculating the practicality of teaching materials according to Riduwan (2009) is as follows

$$
K=\frac{F}{N \times I \times R} \times 100 \%
$$

Description:

$\mathrm{K}$ : Percentage eligibility

$\mathrm{F}$ : Overall number of respondents' answers

$\mathrm{N}$ : Number of respondents

I : Number of questions in the poll

$\mathrm{R}$ : Number of respondents

Tabel 2. Practicallty Interpretation

\begin{tabular}{cc}
\hline Poll Value & Interpretation \\
\hline $81 \%-100 \%$ & Sangat Praktis \\
$61 \%-80 \%$ & Praktis \\
$41 \%-60 \%$ & Cukup Praktis \\
$21 \%-40 \%$ & Tidak Praktis \\
$0 \%-20 \%$ & Sangat Tidak Praktis \\
\hline
\end{tabular}

\section{RESULT AND DISCUSSION}

This research resulted in a learning medium based on virtual basic application or VBA abbreviated on a decent flat build material (Valid, Practical, and Effective). This learning medium will 
be packaged in a learning $C D$ that contains the application and how it is used. The development of this learning medium through the following stages:

1. Definition Stage

The definition stage is the initial stage in the process of developing learning media. At this stage, several analyses are conducted, including curriculum analysis, problem analysis, and student needs analysis

a. Curriculum Analysis

Curriculum analysis is carried out by identifying basic competencies (KD) for rectangular and triangular flat build materials under the revised 2013 curriculum. Rectangular and triangular flat building materials are given to junior high school students in grade VII even semester. There are two basic competencies in rectangular and triangular flat build materials, namely associating the roving and area formulas for different types of rectangles (squares, rectangles, divided, parallels, trapezoids, and kites) and triangles, solving contextual problems related to the area and circumference of rectangles (squares, rectangles, splits, parallels, trapezoids, and kites) and triangles

b. Student Analysis

The student's analysis was conducted on grade VIII students who had obtained rectangular and triangular flat build materials. The analysis was obtained by conducting unstructured interviews about students' difficulties during the learning process of rectangular and triangular flat building materials. Based on the results of the interview obtained several problems faced including students difficulty in understanding the material of flat build rectangles and triangles, students tend to memorize the formula given by the teacher so that when given problems regarding rectangles and triangles in other representations of students difficulties, students still difficult to visualize flat builds rectangles and triangles. This is in line with the statement of Noto et al. (2019) which mentions there are some obstacles and difficulties that are often faced by students, namely a) learning difficulties related to difficulty applying concepts; b) learning difficulties related to visualizing geometric objects; c) learning difficulties related to difficulties in determining principles; d) learning difficulties related to understanding problems and e) related difficulties in a mathematical proof.

c. Needs Analysis

This needs analysis is done based on the results of field surveys. Based on the results of the survey obtained results that at the time of the learning process is needed a learning medium that can increase student activity so that learning is more meaningful.

\section{Design Stage}

After the analysis, the next stage is the media design stage. In the learning media based on virtual basic application, quadrilateral material is provided several tool parameters consisting of length, width, area, circumference, images, magnification, and much more. Figure 1 is a look at the learning media that has been designed 


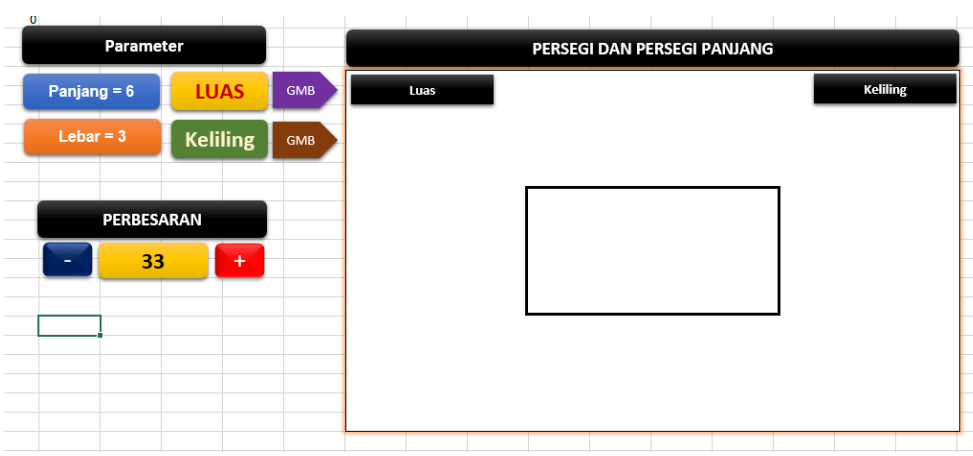

Figure 1. VBA-Based Learning Media

This learning medium can help students find and understand the concept of roving and spacious flat wakes, besides students can calculate the area and circumference of flat builds of different sizes and shapes so that learning becomes more fun and meaningful.

\section{Development Stage}

The next stage is the development stage of virtual basic application-based learning media, where at this stage an assessment of the validity and practicality of the learning media is carried out. The validity assessment was conducted by two experts, namely experts in the field of mathematics and media education while practicality was assessed by teachers and students

a. Validity

The learning media that has been designed will then be assessed its validity by using a validity questionnaire given to material experts and media experts

Table 3. Percentage of Expert Validation

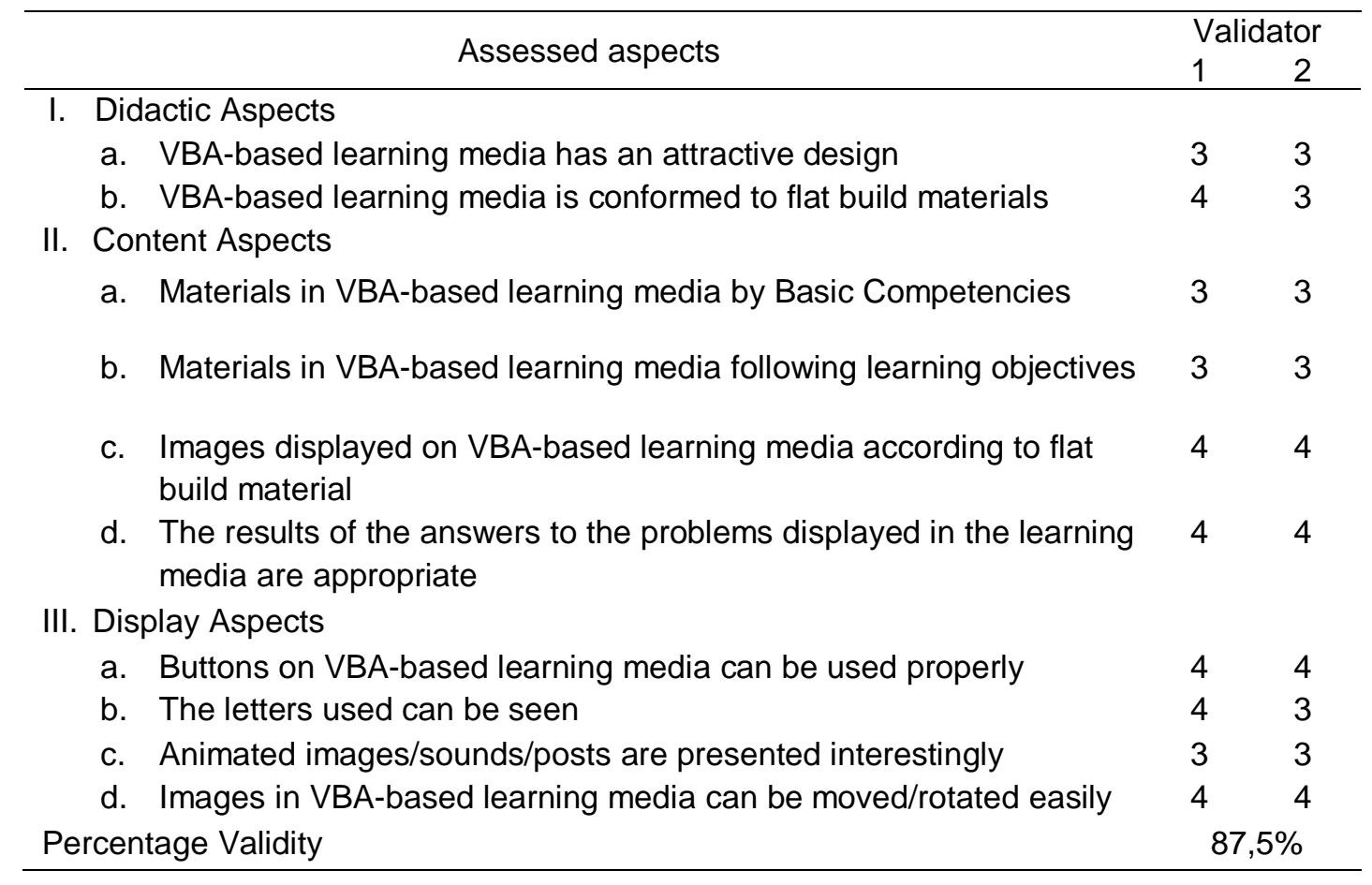


In Table 3. Obtained validity percentage of $87.5 \%$ so based on Table 1 . Then the validity score is included in the "Very Valid" criteria. The input of validator 1 is to add tools for results from the area and circumference as well as tools to check the correctness of the answers that students give. While validator 2 does not provide input on learning media based on virtual basic application. Figure 2 is learning media for the before and figure 3 is learning media after revised.

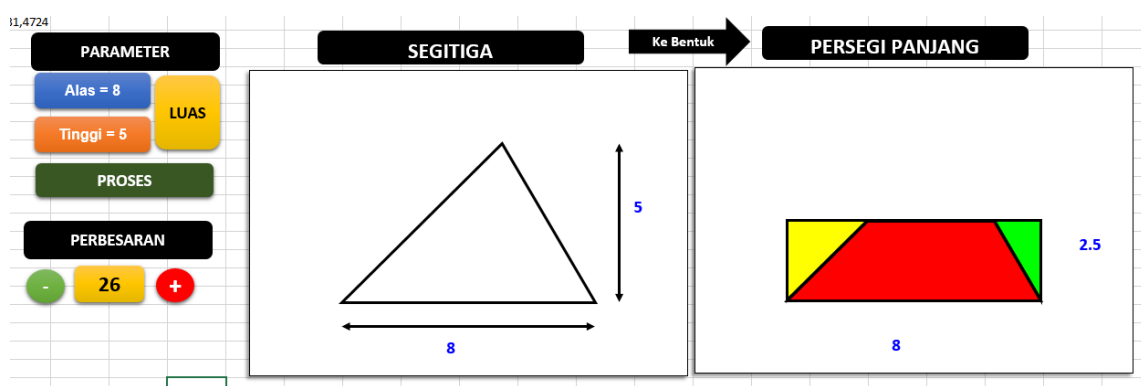

Figure 2. Triangular learning media before revision

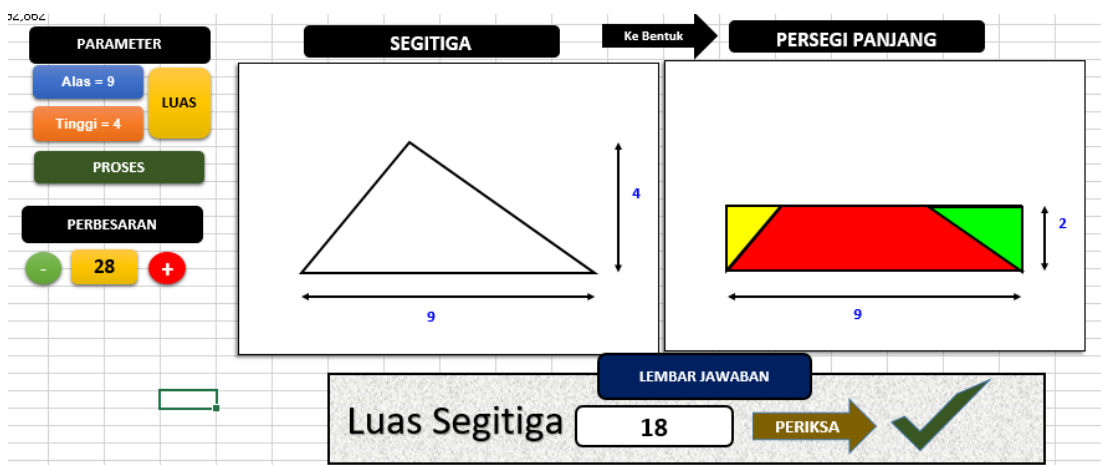

Figure 3. Triangular learning media after revision

Based on the input validator, then as seen in figure 3, several additional tools are answer sheets consisting of the area of the triangle and check so that when the child enters the answer of the area of the triangle according to the base and height that has been entered before, it will appear $\sqrt{ }$ if the answer is correct and $x$ if the answer is wrong. Similarly, learning media for rectangles, given additional tools according to the input of the validator. Figure 4 and 5 are picture of the quadrilateral learning media before and after revision

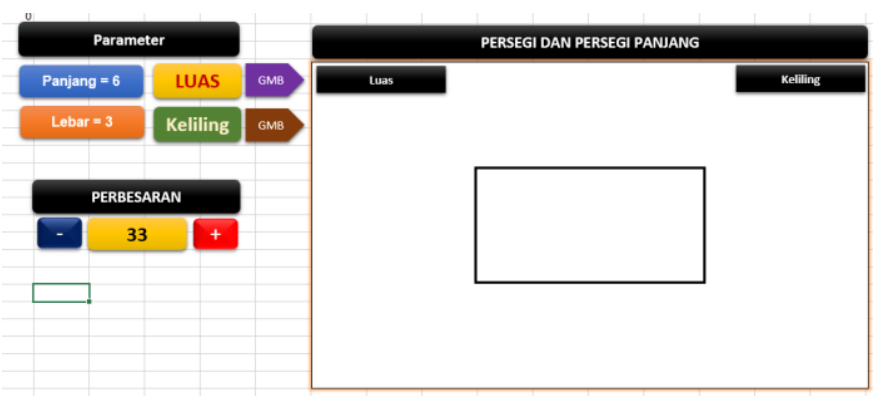

Figure 4. Quadrilateral learning media before revision 


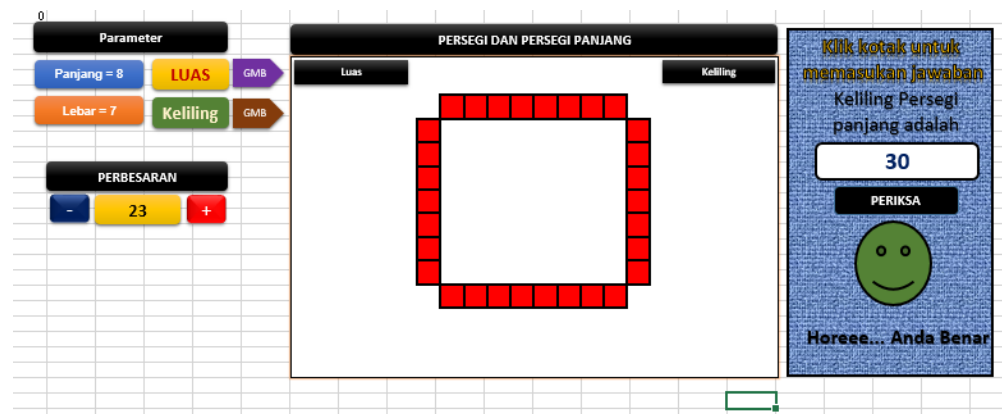

Figure 5. Quadrilateral learning media after revision

\section{b. Practicality}

The practicality of learning media is assessed by two teachers and 30 students. Here are the results of the percentage of the practicality of learning media

Table 4. Percentage of Practicality of Learning

\begin{tabular}{lc}
\hline \multicolumn{1}{c}{ Validator } & Percentage \\
\hline Teacher & $82,4 \%$ \\
Students & $86,19 \%$ \\
\hline
\end{tabular}

Based on Table 4. Obtained the average percentage of the practicality of learning media by $82.14 \%$ and $86.19 \%$ so that it falls into the criteria of "Very Practical". Therefore, learning media based on virtual basic application is according to teachers and students as validators are considered practical in their use and can help students in understanding the concept of the flat building. The aspects assessed include: a) VBA-based learning media has an attractive look, b) VBA-based learning media is easy to use, c) VBA-based learning media can be used quickly, d) the presentation of materials with VBA learning media is more practical, e) the use of writing/images on this learning medium is very effective, f) VBA-based learning media can be used anytime and anywhere, g) VBA-based learning media can be used as a source of learning to build flat.

This learning medium was developed using the use of the virtual basic application in Microsoft excel. The development of this learning media through several stages including the definition stage, the design stage, and the development stage. The definition stage consists of curriculum analysis, student analysis, and needs analysis. The learning media is adapted to the curriculum used today, namely the revised 2013 curriculum, wherein this curriculum students are built competencies and their characters so that students can have smart, critical, creative, innovative skills, curiosity, productivity, and reflection (Harosid, 2018).

Learning media can be developed by teachers according to the needs of students. Learning media has an important role in the learning process. This virtual basic application-based learning media can increase students' interest and activities in the learning process so that learning in the classroom is more fun and more meaningful. One of the studies conducted by (Fang \& Tajvidi, 2018) explains that students who learn by utilizing computer-based technology can significantly increase student activity, in line with Bloom (Fang \& Tajvidi, 2018) that students' 
activities in learning can increase significantly by further building students in the ability to understand, apply, analyze and vaccinate the problems faced by.

\section{CONCLUSION}

Learning media based on Virtual Basic Application is developed through 3 stages including define, design, development (Develop). Based on the trials obtained the following conclusions (1) based on the validity test of VBA-based learning media that has been conducted by 2 experts in the field of mathematics education and learning media, the results were obtained that the designed learning media is valid, and (2) based on the practicality test that has been done, the VBA-based learning media on flat build material is stated to be practical

\section{ACKNOWLEDGEMENT}

The author would like to thank IKIP Siliwangi that supported this research. Furthermore, thanks to all participated students and teachers for their participation in this study.

\section{REFERENCES}

Azhar, A. (2007). Media pembelajaran, Jakarta: PT. Raja Grafindo Persada, 15-85.

Bernard, M., \& Senjayawati, E. (2019). Developing the Students' Ability in Understanding Mathematics and Self-confidence with VBA for Excel. JRAMathEdu (Journal of Research and Advances in Mathematics Education), 4(1), 45-56. https://doi.org/10.23917/jramathedu.v4i1.6349

Bond, M., \& Bedenlier, S. (2019). Facilitating student engagement through educational technology: Towards a conceptual framework. Journal of Interactive Media in Education, 2019(1), 1-14. https://doi.org/10.5334/jime.528

Briz-Ponce, L., Pereira, A., Carvalho, L., Juanes-Méndez, J. A., \& García-Peñalvo, F. J. (2017). Learning with mobile technologies - Students' behavior. Computers in Human Behavior, 72, 612-620. https://doi.org/10.1016/j.chb.2016.05.027

Fabian, K., Topping, K. J., \& Barron, I. G. (2016). Mobile technology and mathematics: effects on students' attitudes, engagement, and achievement. Journal of Computers in Education, 3(1), 77-104. https://doi.org/10.1007/s40692-015-0048-8

Fang, N., \& Tajvidi, M. (2018). The effects of computer simulation and animation (CSA) on students' cognitive processes: A comparative case study in an undergraduate engineering course. Journal of Computer Assisted Learning, 34(1), 71-83. https://doi.org/10.1111/jcal.12215

Gorbi Irawan, A., nyoman Padmadewi, N., \& Putu Artini, L. (2018). Instructional materials development through 4D model. SHS Web of Conferences, 42, 00086. https://doi.org/10.1051/shsconf/20184200086

Habes, M., Salloum, S. A., Alghizzawi, M., \& Motteh, S. (2018). The role of modern media technology in improving collaborative learning of students in Jordanian universities. International Journal of Information Technology and Language Studies, 2, 71-82. https://journals.sfu.ca/ijitls/index.php/ijitls/article/view/51

Harosid, H. (2018). Kurikulum 2013 Revisi 2017. Tersedia Di Https://Scribd. Com. Diakses Pada Tanggal. http://www.academia.edu/download/57483723/GAMBARAN_UMUM_K13_REVISI_2017.pdf

Harris, J. L., Al-Bataineh, M. T., \& Al-Bataineh, A. (2016). One-to-one technology and its effect on student academic achievement and motivation. Contemporary Educational Technology 7 (4), 368-381.

Henriksen, D., Mehta, R., \& Rosenberg, J. M. (2019). Supporting a Creatively Focused Technology Fluent Mindset among Educators: A Five-Year Inquiry into Teachers' Confidence with Technology. Journal of Technology and Teacher Education, 27(1), 63-95. http://search.ebscohost.com/login.aspx?direct=true\&db=eric\&AN=EJ1216023\&site=ehostlive\%0Ahttps://www.learntechlib.org/primary/p/184724/

Ndofirepi, T. M., Rambe, P., \& Dzansi, D. Y. (2018). The relationship among technological creativity, 
self-efficacy and entrepreneurial intentions of selected South African university of technology students. Acta Commercii, 18(1), 1-14.

Noto, M. S., Priatna, N., \& Dahlan, J. A. (2019). Mathematical proof: The learning obstacles of preservice mathematics teachers on transformation geometry. Journal on Mathematics Education, 10(1), 117-125. https://doi.org/10.22342/jme.10.1.5379.117-126

Nuryanto, K., \& Zaki, S. (2012). Program Aplikasi Perhitungan Premi Asuransi Jiwa Dengan Macro Dan Excel Visual Basic for Application (Vba). Jurnal Matematika, 1(1), 108-117.

O'neil, T. (2012). Multiple Intelligences: The concept of distributed intelligence in Gardner's theory of Multiple Intelligences. Psychology of Education, 1-52.

Shih, K.-P., Chen, H.-C., Chang, C.-Y., \& Kao, T.-C. (2010). The development and implementation of scaffolding-based self-regulated learning system for e/m-learning. Journal of Educational Technology \& Society, 13(1), 80-93.

Sung, Y. T., Chang, K. E., \& Liu, T. C. (2016). The effects of integrating mobile devices with teaching and learning on students' learning performance: A meta-analysis and research synthesis. Computers and Education, 94, 252-275. https://doi.org/10.1016/j.compedu.2015.11.008

Taufik, M., \& Kristanto, A. (2018). Pengembangan Mobile Learning Berbasis Aplikasi Android Mata Pelajaran Fisika Materi Listrik Arus Searah Kelas Xi Smk Negeri 2 Kediri. Jurnal Mahasiswa Teknologi Pendidikan, 9(2), 1-8.

Yen, H. C., Tuan, H. L., \& Liao, C. H. (2010). Investigating the Influence of Motivation on Students' Conceptual Learning Outcomes in Web-based vs. Classroom-based Science Teaching Contexts. Research in Science Education, 41(2), 211-224. https://doi.org/10.1007/s11165009-9161-x 